\title{
Sedimentation Model Area of Lau Kawar Lake from Volkanic Eruption of Sinabung Mountain in Karo District, North Sumatra Province
}

\author{
Said Muzambiq
}

Geological Engineering Department, Institute Technology of Medan, Sumatera Utara, Indonesia

\begin{abstract}
Lau Kawar Lake is a VolkanicLake has wide around 200 hectares which below hillside of Sinabungmountain located in Kutagugung Village, District Naman Teran, Karo District, North Sumatera Province. Impact eruption ofmount Sinabungis Volkanic material in the form of important from clastic sediment to be donere search. Purpose of this research is HIBAH Dikti 2016 year, item to know type of sediment that is election mean, sorting, skewness and curtos is. and deposition public area of sediment volkanic post eruption of Sinabung.

Primary data collection activities sediment core with PVC core method. generates data in the form of characters sediment grain size, sedimentary structures, sediment composition and sedimentary depositional environment interpretation presented inthe stratigraphic column Lake Lau Kawar.

Calculation method applied that is, Method of Moments (Mathematic) and Folk \& Ward (Graphic). Result of sediment material analysis in 15 points, value mean either graphically mathematical and also shows flattening - plane of grain size coarse sand - very fine sand, Value sortasimoderately sorted - poorly sorted, Value skewnwessat smooth and rugged normal same relative distribution like at sample LK 11 LK 12 LK 13 LK 34 and LK 53, Curtosis value from overall of sample included in classification of finite mesokurtic of leptokurtic ( $K c=0,90-1,1$ and $K c=1,11-1,50)$. Crossplot between values $Y 1$ and $Y 2$ indicates that deposition area to stay at [shallow/superficial] deposition area at Y2 and y3 stays at fluvialarea of marine, at $Y 3$ and $Y 4$ still residing in at fluvial deposition area of marine Data analysis result of screening of sediment sample isdone to applies GRADISTAT, a programproposed by BlottandPye (2011) and developed by Kenneth Pye Associates Ltd. Software GRADISTAT implemented in program Microsoft Excel.
\end{abstract}

Keyword- Sedimentation, Lau Kawar, Volcanic Eruption, Sinabung mountain, PVC core method.

\section{INTRODUCTION}

The study discusses about the lake through sedimentology studies in Indonesiais still a bit todo, especially for a lake formed by volcanic or volcanic activity. Lake as a waterbody shaped hollows on the surface of the Earth can serve as indicators of natural ecosystems and the stability of the sumounding environment. In the case of lakes associated with volcanic activity, the lake also can be used as an indicatortodetermine the activities that took place surrounding volcanoes.

Lake Lau Kawarexample is one example of the lake forming as sociated with volcanic activity, on Mount Sinabung (Figure 1.1 and Figure 1.2) located in Karo, North Sumatra. Geographcally, the presence of Lau Kawarlake which is right at the foot of Mount Sinabungput this lake as one of the areas affected directly against volcanism especially sediments materials happened. It makes Lake Lau Kawarare the areas most appropriate to be used as a researchlocation.

Geological aspect which addresses specifically about sedimentology will be assessed properly by studying the condition of sedimentation that took place in the Lake Lau Kawar which has an area of approximately 200 hectares located in the village of Kutagu-gung, District NamanTeran, under the foot of the volcano Sinabung, Karo, North Sumatra Province.

Increased volcanic activity of Mount Sinabung in the last 5 years as well as ongoing eruption since 2013 and is cumently producing a variety of types and sediment material contained in the waters of Lake Lau Kawar become the main back ground research, especially granulometry. Granulometriis material grain size analysis method so that it can be seen how the transport properties, shape and grain size as well as the deposition environment.

Based on the background of the above, then there is some problem formulation needed to know the history of the depositional environment of the lake Lau Kawar located at the foot of Mount Sinabung among other things, how to determine the distribution of the deposition of sediment material vulkaniklastik the enuption, how to know the texure of the material granulametri the eruption, and environmental factors are influential model of sediment deposition after the eruption of Mount Sinabung. The purpose of research, is to know whatand how to model and characteristics of Sedimentary environments that exist in the region resent Lau Kawarlake. The village is located Kutagugung, District Naman Teran North Sumatra after the eruption Sinabungvolcano. The contribution of this study 
support the construction and acquisition of baseline data for the development of science-related volcanicsediment.

Sedimentation process also affects the characters resent sediments deposited ina basin. Media and transport mechanisms will affect sediment grain size, the variation form sedimentary structures. There was alsoa time factor affecting the length of the process of sedimentation sediment grain size. Sedimentary bas in as a place to settle also have different properties related to environmental conditions. General conditions deposited sedimentary basins place called the depositional environment. Bentl (2001), describes the particle sediment is the result of the weathering of rocks, the biological material, chemical deposition, dust, materialremains of plants and leaves.

The research objective was to determine the characteristics of sedimentary material resent that granulametri nature, environment sedimentation of the lake, and the history of the deposition from the eruption of volcanoes Sinabung. The contribution of this study support the construction and acquisition of baseline data for the development of science.

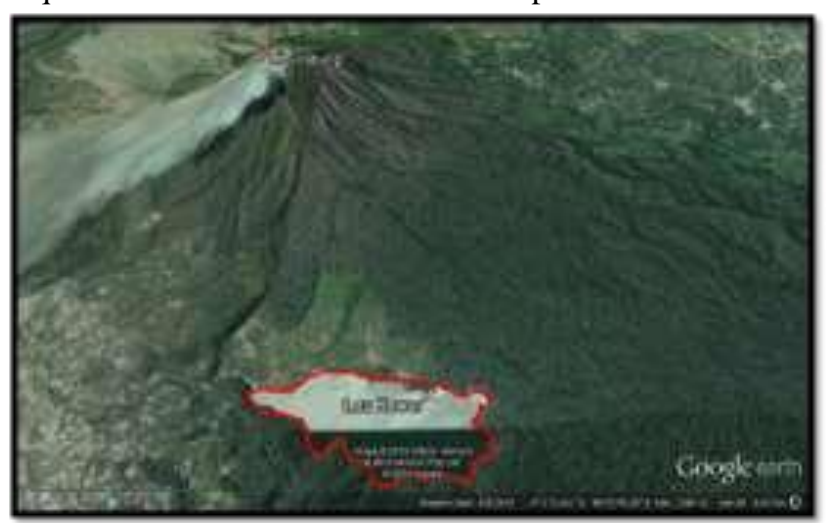

Fig.1: Google Earth's image location LauKawar Lake and Volcano Sinabung

\section{METHODOLOGY}

\section{Location}

The research was conducted on Lau Kawarlake area in the village Kutagugung, Sub-District Naman Teran(first Sub-Dis trict Simpang Empat), under the foot of the volcano Sinabung, Karo District, North Sumatra Province. Thelake extents2.127,25 $\mathrm{km} 2$ with a depth of 22 meters is located the foot of Mount Sinabung, Karo and is part of the Hutan Wisata Delengareas.

\section{Type Methods}

The method used is research and descriptive. Furthermore, the data were analyzed using four (4) models approaches namely: descriptive approach, historical approach sediment, conceptual approach, and comparative grain size approach. In the implementation of sampling recent sediment cores the field with PVC Coring obtained 15 samples of sediment core resent with varying depths. Megascopics methods and laboratory analysis (granulometri) to determine the physical properties of the sediments. Megascopic sediment analysis using the parameters of texture and sedimentary structures.Texture analyzed were grain size, grain shape and sorting sediments. Analyzed sedimentary structures analyzed were conditions layering on a sediment core. It also made observations of sediment content such as the existence of a carbonaceous content or calcareous content inthesedimentcore. Based on the analysis performed on a sediment core obtained physical condition of sediment which is then presented in the statistical data, especially the texture parameters of the sediment, where the results are then analyzed by a laboratory test.Analysis of data from the sifting of sediment samples was performed using GRADISTAT, a program proposed by Blottanand Pye(2011) and developed by Kenneth Pye Associates Ltd. Software GRADISTAT run in Microsoft Excel program Calculation method used, namely, Method of Moments (Mathematical) and Folk \&Ward (Graphic) in Sedimen to logical Laboratory of Universtas Gadjah Mada (UGM) in Yogyakarta.

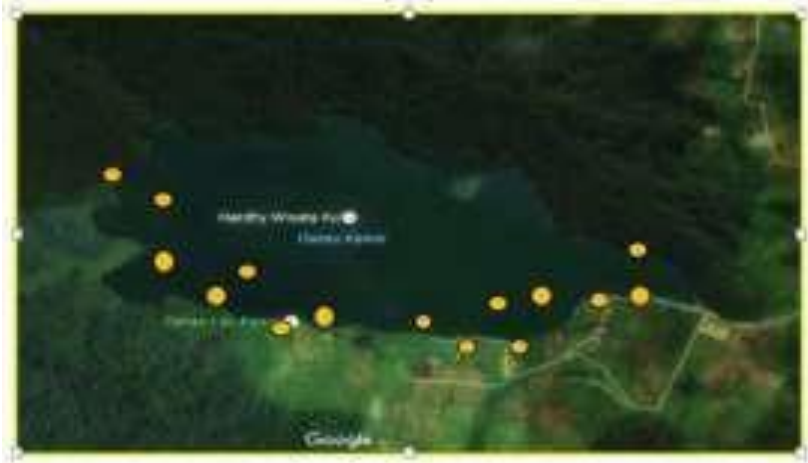

Fig.2: Map of Data Retrieval PVC Core Sediment Samples Lake Lau Kawar

\section{RESULT}

Has conducted sampling method coring against Lau Kawarlake sediments resent as much as 15 sample points. Based on the data tabulation description of the sorting of the overall analysis of the sample can be in sorting or level of unifomity of grain sediments are generally a group again sorting poor to moderate because of the layers of sediment are generally prepared by grain - fine grain size of mud to sand as shown in the results analysis of statistical calculations which each sample is dominated by fine sand-sized minerals to mud.

Based on the analysis performed on a sediment core obtained physical condition of sediment which is then presented in the statistical data, especially in sediment texture parameter descriptions PVC Core profile (Figure3).

Sediment grain size indicates that the hydrodynamic flow conditions that work on Lake Lau Kawar environment and surroundings have the power measuring sediment transporting sand tothe weak currents which can only move the silt sized sediment. 


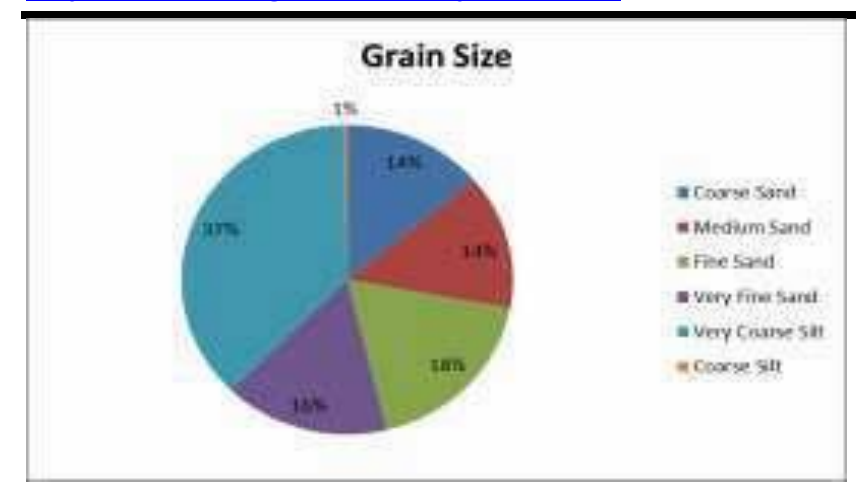

Fig.3: Diagram of Particle Size Distribution of Sediment From PVC Coring

Grain shapes are represented by the type of grain roundness showed sediment from a sediment core obtained from the implementation of the PVC Coring is dominated by rounded shapes and rounded being. It is clear that sediment has been obtained from sources of sediment that have been transported long distances to middle of sedimentary environments that exist in the region Lau Kawarlake and its sumoundings. Can be interpreted also that these sediments are generally derived from the rivers that enter to lake system that also serves as a source of sediment in Lake Lau Kawar.

Sorting obtained from the analysis of sediment cores show a trend of poorly sorted, where sorting sediment grains are not uniform due to the instability of currents that carry sediment and during the deposition of sediments. Sorting both the results of the analysis explained that the current instability does not occur in all depositional environments that existinthe lake LauKawar. Further data analysis results using GRADISTAT sieving sediment samples, method of Moments (Mathematical) and Folk \& Ward (Graphic) in Sedimento logical Laboratory of Universtas Gadjah Mada(UGM, 2016) Yogyakarta, Indonesia is as follows:

Table.1. Results of the analysis on 15 samples of sediments Granulometric

\begin{tabular}{|c|c|c|c|c|}
\hline Sampei & Mean & Sortasi & Skewness & Kurtasis \\
\hline $1,5.1$ & 1.449 & 1.297 & 0.210 & 0.920 \\
\hline $\operatorname{LK} 1.2$ & 1.361 & 1,380 & 0,337 & 0.797 \\
\hline LK 1.3 & 1.456 & 0,969 & $-0,036$ & 0,070 \\
\hline LKT 4 & 4.447 & 0.465 & $-0,305$ & 1,421 \\
\hline$L K \geqslant 1$ & 4560 & 0,278 & -0.070 & 0. is? \\
\hline$L K=3,1$ & 3644 & 1,171 & -0.408 & 0,790 \\
\hline LK 32 & $2,80.4$ & 1.042 & $-0,170$ & D, abe \\
\hline LK 3.3 & 3,842 & 1.002 & $-0,528$ & $12 \mathrm{~B} 4$ \\
\hline L.K 3.4 & 3.290 & 0,042 & $-0,005$ & 0.801 \\
\hline LK 3,5 & 3,421 & 0.739 & -0.007 & 1,095 \\
\hline LK 4.1 & 2.705 & 1.400 & $-0,392$ & 0.697 \\
\hline LK. 4.2 & 4.555 & 0,351 & $-0,181$ & 1,156 \\
\hline LK 51 & 1.050 & 1.286 & 0.067 & 0.930 \\
\hline LK 5.2 & 1284 & 0,920 & 0,062 & 0.895 \\
\hline LK 5.3 & 1.778 & 1.516 & 0.112 & D. 85.4 \\
\hline
\end{tabular}

Based on the Granulo metric analysis performed, and by analogy that the samples taken on LK at 1 STA has a relationship with LK others. If the sampling is not random but linearthen: a. At LK 1.1 to 1.4 relative occurs reduction of energy deposition shown from LK mean values of $1.1-1.4$ is decreased, except in LK 1.2 that increased energy deposition, which then decreased energy deposition. Based on analysis of sorting impaired sorting (more well sorted), except in LK 1.2 which has increased the value sorting.

b. At LK 2.1 sediments deposited in low energy deposition, on a relatively quiet environment so that the grain size of silt can be deposited, it is also shown by the sorting value that indicates well sorted. When viewed based on an analysis of grain size can about that LK 1.4, 2.1 LK,LK4.2 deposited on environmental conditions are relatively similar; an environment of the quiet stream, for example in the flood plain on the river morphology.

c. At LK 3.1 - 3.5 LK 1,2,3,4,5when sorted by grain size (mean) do not reflect a meaningful relationship in which the mean value of random. But when grouped into 2 groups: group 1 consists of LK 3.1 \& LK 3.3 and Group 2 consists of LK 3.2, LK 3.4, and LK 3.5, then both groups showed a decrease in the value of the grain size (energy deposition)and impairment sorting (increasingly wells orted).

d. LK 4.1 and 4.2 on a decline in energy deposition shown to increase the finefrom the existing sediment grain size(mean). Sorting at 4.1 and 4.2LK relatively impaired sorting (more wells orted).

e. At LK LK5.1 and 5.3 relative decline seen energy deposition of increasingly fine grain size (mean) of the value of the previous LK sorting unlike an increasing rate of sorting (increasingly poorly sorted). LK 5.2 has an energy deposition is relatively the largest among LK 5.1 and5.3sorting value most sorting relatively low (more well sorted) of the LK 5.1 and LK. 5.3.

In the following picture, is one of the tabulated data showing that quartesic whole of data analysis, statistical calculations and data phi cumulative histogram curve showed two types of diagrams histogram is unimodaland bimodal. In this case the whole sample showed cumulative histogram curve phidominated by a diagram showing the cusp or unimod also that it can be interpreted sediments. Deposition area than those that are in the area of coastal sediment / river that has the characteristics.

Here is one example of the data analysis results sieving sediment samples was performed using GRADISTAT, a program proposed by Blottand Pye(2011) and developed by Kenneth Pye Associates Ltd. Software GRADISTAT run in Microsoft Excel program. Calculation method used, namely, Method of Moments (Mathematical) and Folk \& Ward (Graphic)

Further analysis of the data using GRADISTAT produce sorting varied group description. Group sorting of each test sample can be seen in Table 2 below. 
Tabel.2: Granulo metric cummulative table

\begin{tabular}{|c|c|c|c|c|c|c|}
\hline Mesh & Phi unit & $\begin{array}{c}\text { Diameter } \\
(\mathrm{mm})\end{array}$ & Grain Size & \begin{tabular}{|c|}
$\begin{array}{c}\text { Fraction } \\
\text { (gr) }\end{array}$ \\
\end{tabular} & $\begin{array}{c}\text { Frequency } \\
\text { (\% Fraction) }\end{array}$ & Cumulative (\%) \\
\hline 18 & $<0$ & 1 & Very Coarse Sand & 11,4 & 11,85 & 11,85 \\
\hline 35 & $0-1$ & 0,5 & Coarse Sand & 26 & 27,03 & 38,88 \\
\hline 60 & $1-2$ & 0,25 & Medium Sand & 29,4 & 30,56 & 69,44 \\
\hline 120 & $2-3$ & 0,125 & Fine Sand & 16,9 & 17,57 & 87,01 \\
\hline 230 & $3-4$ & 0,0625 & Very Fine Sand & 4,8 & 4,99 & 92,00 \\
\hline 270 & $4-4,25$ & 0,053 & Silt & 4,8 & 4,99 & 96,99 \\
\hline$>270$ & $>4,25$ & $<0,053$ & Clay & 2,9 & 3,01 & 100,0 \\
\hline \multicolumn{4}{|c|}{$\mathrm{T}$} & 96,2 & 100 & 100 \\
\hline
\end{tabular}

Table.3: Description Tabulation Sorting

\begin{tabular}{|l|l|l|c|l|}
\hline No & Poorly Sorted & Moderately Sorted & Well Sorted & Very Well Sorted \\
\hline 1 & LK 1.1 (Bimodal) & LK 1.3 (Unimodal) & LK 1.4 (Unimodal) & LK 2.1 (Unimodal) \\
\hline 2 & LK 1.2 (Bimodal) & LK 3.4 (Bimodal) & LK 4.2 (Unimodal) & \\
\hline 3 & LK 3.1 (Bimodal) & LK 3.5 (Unimodal) & & \\
\hline 4 & LK 3.2 (Unimodal) & LK 5.2 (Unimodal) & & \\
\hline 5 & LK 3.3 (Unimodal) & & & \\
\hline 6 & LK 4.1 (Unimodal) & & & \\
\hline 7 & LK 5.1 (Bimodal) & & & \\
\hline 8 & LK 5.3 (Bimodal) & & & \\
\hline
\end{tabular}

Overviews of the depositional environment of the test sample can be obtained from the statistical parameters using the analysis function of discrimination raised by Sahu(1964).

The use of bivariate scatter plots proposed by Moiola and Weiser (1968) and Friedman (1961) also used to get a general overview of the depositional environment of the test sample.

Values of mean, sorting, skewness, and curtosis for each test sample can be seen in Table 2 and Table 3.

Here is presented a sample graphic of grain characteristics (mean, sorting, skewness, and curtosis) for each sample (figure 4 and 8 for sample). Overview depositional environment ofthe test sample can be seen on the plot charts by making crossplotbetween Y1, Y2, Y3 and Y4 as presented figure9.

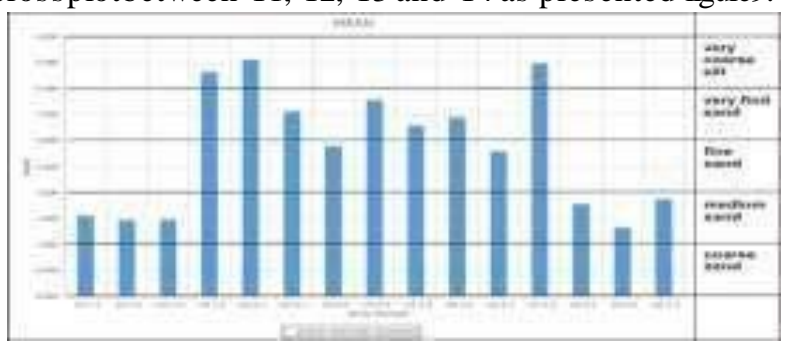

Fig.4: Grain characteristics (mean, sorting, skewness, and curtosis) from sample $L K-1$

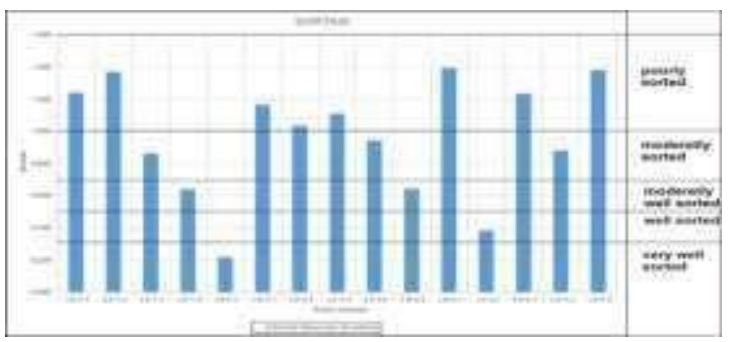

Fig.5: Grain characteristics (mean, sorting, skewness, and curtosis)from sampleLK-2

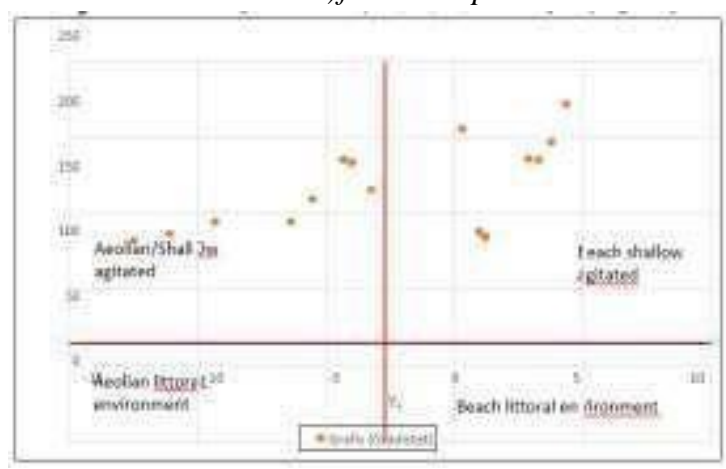

Fig.9: Depositional Environment fromLK-1 
Table.4: Tabulation Characteristics Sample Test

Granulas (Mathematical Methods GRADISTAT)

\begin{tabular}{|l|l|r|r|r|}
\hline Sample & Mean & Sorting & Skewnes & Curtosis \\
\hline LK 1.1 & 1,552 & 1,243 & 0,769 & 2,816 \\
\hline LK 1.2 & 1,475 & 1,372 & 0,809 & 2,630 \\
\hline LK 1.3 & 1,479 & 0,864 & 0,092 & 2,319 \\
\hline LK 1.4 & 4,325 & 0,641 & $-2,987$ & 13,530 \\
\hline LK 2.1 & 4,563 & 0,220 & $-3,830$ & 17,310 \\
\hline LK 3.1 & 3,564 & 1,166 & $-0,810$ & 2,700 \\
\hline LK 3.2 & 2,900 & 1,036 & $-0,587$ & 2,911 \\
\hline LK 3.3 & 3,783 & 1,112 & $-1,509$ & 4,476 \\
\hline LK 3.4 & 3,295 & 0,944 & $-0,448$ & 3,070 \\
\hline LK 3.5 & 3,447 & 0,645 & $-0,030$ & 2,379 \\
\hline LK 4.1 & 2,796 & 1,395 & $-0,522$ & 1,940 \\
\hline LK 4.2 & 4,488 & 0,385 & $-3,451$ & 15,700 \\
\hline LK 5.1 & 1,786 & 1,238 & 0,439 & 2,414 \\
\hline LK 5.2 & 1,328 & 0,882 & 0,678 & 3,423 \\
\hline LK 5.3 & 1,875 & 1,381 & 0,375 & 2,199 \\
\hline
\end{tabular}

Overview depositional environment obtained from bivariate plot as noted by Moiola and Weiser (1968) and Friedman (1961) presented in the graphsbelow.

Table.5: Characteristics of Grain Sample Tabulation Test (Graphic Methoda GRADISTAT)

\begin{tabular}{|l|l|r|r|r|}
\hline Sample & Mean & Sorting & Skewnes & Curtosis \\
\hline LK 1.1 & 1,449 & 1,297 & 0,218 & 0,928 \\
\hline LK 1.2 & 1,361 & 1,380 & 0,337 & 0,797 \\
\hline LK 1.3 & 1,456 & 0,959 & $-0,036$ & 0,875 \\
\hline LK 1.4 & 4,447 & 0,495 & $-0,305$ & 1,421 \\
\hline LK 2.1 & 4,589 & 0,278 & $-0,070$ & 0,857 \\
\hline LK 3.1 & 3,644 & 1,171 & $-0,408$ & 0,790 \\
\hline LK 3.2 & 2,964 & 1,042 & $-0,170$ & 0,886 \\
\hline LK 3.3 & 3,842 & 1,092 & $-0,528$ & 1,264 \\
\hline LK 3.4 & 3,298 & 0,942 & $-0,055$ & 0,801 \\
\hline LK 3.5 & 3,421 & 0,733 & $-0,097$ & 1,039 \\
\hline LK 4.1 & 2,785 & 1,400 & $-0,392$ & 0,697 \\
\hline LK 4.2 & 4,555 & 0,351 & $-0,181$ & 1,156 \\
\hline LK 5.1 & 1,658 & 1,296 & 0,087 & 0,938 \\
\hline LK 5.2 & 1,284 & 0,929 & 0,062 & 0,899 \\
\hline LK 5.3 & 1,778 & 1,516 & 0,112 & 0,854 \\
\hline
\end{tabular}

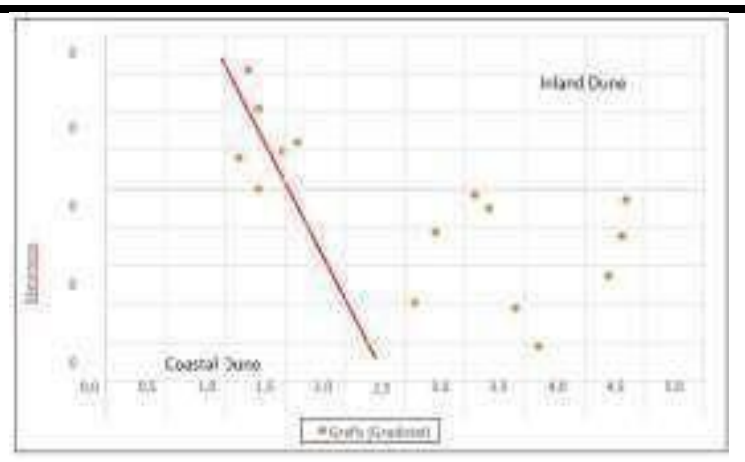

Fig.6: Depositional Environment Crossplot from LK-1

\section{CONCLUSIONS}

1. The mechanism of transport of sediment in the sample indicates that the transport mechanism is very influential in sediments are suspended load and deposition processes on the river.

2. In the mechanism that is where the suspended load sediment materials tertransportasikan by river, by floating above the bottom of the river by the flow of water turbulence. So that the transported material will generally produce the grain size of silt to clay as ditunjukkan the statistical calculation data on how many samples between 1.4 sample LK LKLK2.1 3.19 In the deposition process streams according to Thombury1964; where the river can no longer transport the material - material he was carrying. It is influenced by factors decrease the flow rate of the river, the addition of material that is transported on the river, its flow is reduceddue to climate change, as well as their results by the wind deposition of thick and extensive consisting of grain size of clay, silt, and sand. This can be seen by the data analysis on the curve grain size distribution in the sample, which showed an increase and cumulative particle diameter phidrastic thus producing two peak on cumulative histogram phi diagram As well as a greater percentage relative presence of granules composed ofs and-sized grains like that are shown in the data sample statistical analysis results.

3. Characteristics of Pellets and results tabulation Discrimination function test samples in Table 3, it produced some of the data are then displayed in the chart overview depositional environment of the test sample that can be seen in the graph plot by making cross plot between nilayY1, Y2, Y3 and Y4 as presented.Where on cross plot between the Y1 and Y2 indicate that the sedimentary depositional environment than it is on the shallow depositional environment that is influenced by the relative flow speed is quieter, the $\mathrm{Y} 2$ and $\mathrm{y} 3$ is in an environment where there are marine fluvial influence of flow rate water is fairly quiet. In Y3 and Y4 is still in the marine fluvial depositional environment but inthis environment has affected the water flow in the turbiditesediments. Each of 
sediment deposition will be influenced by the rate of water flow, conditions of lithology area depositional environments, physical processes during transport, climate conditions, the density of granules of sediment conditions of weathering and the distance of transportation thana grain of sediment from the initial site / host rock to the accumulation of granules - granules so deposited back (tersedimentasi) the farther the distance as well as the water flow rate fluctuations will result in a material with a grain shapes more rounded.

\section{REFERENCES}

[1] Boggs, Sam Jr., 2006, "Principles of Sedimentology and Stratigraphy: Fourth Edition", USA : Pears on Prentice Hall.

[2] Blott, S.J. danPye, K., 2001.“GRADISTAT: A GrainSize Distribution and Statistics Package for The Analysis of Unconsolidated Sediments". Earth Surface Processes and Landforms 26, 1237 -1248.

[3] Doust, Harry danNoble, A. Ron, 2007, "Petroleum System Of Indonesia", Indonesia :Marine and Petroleum Geology, Elsevier

[4] Eko Minarto, Heron Surbakti, Elizabeth Vorandra, Tjiong GiokP in, Muzilman, Musli, Eka Saputra, 2013.“Kaitanaktivitas vulkanik dengan Distribusi Sedimensan Kandungan Suspensidi Perairan Selat Sunda".

[5] Folk dan Ward (1957) dalam Surjono, S.S.,

[6] D. HendraAmijaya, SarjuWinardi, 2010, “Analisis Sedimentologi", Pustaka Geo, Yogyakarta.

[7] Friedman, G.M.,1961, "Distinction between Dune, Beach and River Sands from Their Textural Characteristics". Journal of Sedimentary Petrology, Vol.31, No.4, pp. 514-529.

[8] Johnson, L. Cari, 2004, "Sedimentology and Reservoir Architecture of a Synrift Lacustrine Delta, South Eastern Mongolia", USA :Journal of Sedimentary Research

[9] McCaffrey, Robert, 2008, "The Tectonic Frame work of the Sumatran Fault SubductionZone", New York :Rens selaer Polytechnic Institute

[10] Midleton, V. Gerard, 2003, "Encyclopedia of Sedimentand Sedimentary Rocks :Sedimentology, History", Canada : Springer (p.628)

[11] Milliken, L. Killy, 2003, "Encyclopedia of Sediment and Sedimentary Rocks :Diagenesis", Canada : Springer (p. 214)

[12] Moiola, R.J. danWeiser, D., 1968, "TexturalParameters and Evaluation.Journal of Sedimentary Petrology", Vol. 38, No.1, pp. 45 - 53 .

[13] Nichols, Gary, 2009, "Sedimentology and Stratigraphy: Second Edition", United Kingdom
: Wiley-Blackwell Publishing.

[14] Reading, G. Harold, 1996, "Sedimentary Environtment: Processes, Facies and Stratigraphy", United Kingdom : Blackwell Publishing Limited (p.89-91)

[15] Seclley, C. Richard, 2000, "Applied Sedimentology”, United Kingdom : Royal School of Mines (p.195,197)

[16] Sieh, Kerry. 2000. "Neotectonics of the Sumatran Fault, Indonesia". Indonesia : Journal of Geophysical Research

[17] Surjono, S.S., D. Hendra Amijaya, Sarju Winardi, 2010, “Analisis Sedimentologi”, Pustaka Geo, Yogyakarta.

[18] Tucker, M.E., 1996, "Sedimentary Rocks in the Field", Chichester : John Wiley \& Sons, (p. 135)

[19] Walker, G. Roger, 1992, "Fasies Model : Response to Sea Level Change" Canada : Geological Association of Canada (p. 3)

[20] Wikipedia.org. 2013. "Sedimentary Structures", http//en.wikipedia.org/wiki/_Sedimentary_structures 